\title{
PEMAHAMAN GENDER PNS DI LINGKUNGAN DINAS PEMBERDAYAAN PEREMPUAN DAN PERLINDUNGAN ANAK PEMERINTAH DAERAH KABUPATEN BENGKALIS
}

\author{
Mufaro'ah \\ STAIN Bengkalis, muf.roha@gmail.com \\ Titin Sumarni \\ STAIN Bengkalis, titinijal@gmail.com
}

\begin{abstract}
This article is about the understanding and the implementation of civil servants' gender understanding in the Department of Women's Empowerment and Child Protection in Bengkalis Regency Government. In addition, it also asks the public response on the implementation of program-based gender conducted by the civil servant. The data obtained through the questionnaires toward 36 respondents and did the interviews to the informants who have been chosen based on various interests. This data was analyzed by descriptive qualitative analysis. The results found that the civil servants' understanding based on gender in Department of Women's Empowerment and Child Protection of the Bengkalis Regency Government already understands the gender well, so that the programs carried out always consider welfare based on gender equality. In addition, it contributes to the strengthening public knowledge about welfare based on gender equality.
\end{abstract}

Keyword: Gender, Women empowerment, child protection, PNS, Bengkalis

\begin{abstract}
Abstrak
Artikel ini tentang pemahaman dan impelemtasi dari pemhaman gender PNS pada Dinas Pemeberdayaan Perempuan dan Perlindungan Anak Pemerintah Daerah kabupaten Bengkalis. Di samping, itu juga diteliti respon masyarakat tentang implementasi program tentang berbasis gender yang dilakukan PNS tersebut. Data diperoleh melalui angket kepada 36 responden dan wawancara kepada informan yang telah dipilih berdasarkan berbagai kepentingan. Data ini dianalisis dengan kualitatif deskriptif. Dari hasil analisis ditemukan bahwa pemahamanan gender PNS di Dinas Pemeberdayaan Perempuan dan Perlindungan Anak Pemerintah Daerah kabupaten Bengkalis sebahagian besar sudah memahami gender dengan baik, sehingga programprogram yang dilakukan selalu mempertimbangkan kesejahteraan berbasis kesetaraan gender. Di samping itu, berkontribusi dalam memperkuat pengetahuan masyarakat tentang kesejahteraan berbasis kesetraan gender tersebut.
\end{abstract}

Kata Kunci : Gender, PNS, Pemberdayaan Perempuan, Perlindungan Anak PNS, Bengkalis 


\section{Latar Belakang}

Salah satu tujuan penting dari pembangunan berwasasan gender adalah peningkatan kualitas hidup perempuan. Hal itu bisa tercapai dengan cara meningkatkan kapabilitas dasar perempuan, terutama untuk aspek pendidikan dan kesehatan. Oleh sebab itu pihak yang terlibat dalam pembangunan manusia yang berkualitas harus memiliki pengetahuan tentang pembangunan berwawasan gender itu. Pengetahuan itu akan berimplikasi dan berdampak terhadap tindakan dan prikaku seseorang. Dalam konteks ini, dapat difahami bahawa pembangunan harus diwujudkan dengan kesetaraan gender.

Dalam rangka mewujudkan kesetaraan dan keadilan gender. Diperlukan melakukan edukasi kepada masyarakat tentang pemahaman gender untuk dapat membedakan antara jenis kelamin dan gender. Setelah masyarakat mampu untuk membedakan antara gender dan jenis kelamin baru masyarakat dikenalkan dengan kesetaraan dan keadilan gender. Dengan mengubah cara pandangan masyarakat akan kesetaraan dan keadilan gender tentu tindakan diskrimanasi pada salah satu jenis kelamin baik laki-laki ataupun perempuan tidak akan terjadi ${ }^{1}$.

Ketidakadilan Gender bukan hanya ditujukan kepada perempuan semata akan tetapi kepada seluruh elemen masyarakat. Sering kali permasalahan gender erat kaitanya dengan perempuan, karena perempuan dominan untuk mengalami ketidakadilan gender. Menyebabkan perempuan sering termarjinalisasi didalam berbagai aspek kehidupan ${ }^{2}$.

\footnotetext{
${ }^{1}$ Arjani NL. Ketimpangan gender di beberapa bidang pembangunan di Bali. Jurnal Studi Jender. 2003;3(2).

2 Leny, O. (2016). Perlawanan Perempuan Terdadap Dominasi Laki-Laki Dalam Novel Naruto Hicho Karya
}

Pemahaman akan kesadaran gender sangat diperlukan untuk mewujudkan kesejahteraan bagi perempuan dengan menerapkan programprogram pengarusutamaan gender. Oleh karena itu diperlukan PNS (Pegawai Negeri Sipil) untuk memiliki pemahaman akan kesetaraan gender itu, agar program keja yang dilaksanakan untuk mengwujudkan kesejahteraan masyarakat mngunakan pendekatan pengarusutamaan gender ${ }^{3}$. Tujuannya adalah, supaya dalam pembangunan dan peningkatan kualitas hidup tidak terjadi marjinalisasi dan tidak terjadi ketimpangan yang sangat merugikan dalam pembangunan manusia yang berkualitas itu.

Pemahaman gender yang dimiliki oleh PNS harus di implementasikan kepada program kerja yang pengarusutamaan gender. Maka PNS yang ada dalam ruang lingkup Dinas Pemberdayaan Perempuan Dan Perlindungan Anak sangat perlu memiliki pemahaman gender itu, sebab kelompok ini sebagai leading sektor untuk membangun kualitas manusia berbasis keadilan dan kesetaraan gender itu.

Oleh sebab itu penelitian ini, dilakukan dilingkup PNS Dinas Pemberdayaan Perempuan Dan Perlindungan Anak Pemerintah Kabupaten Bengkalis, dinas ini merupakan leading sectornya di Kabupaten Bengkalis.

\section{Metodologi}

Penelitian ini dilakukan di Dinas Pemberdayaan Perempuan Dan Perlindungan Anak Pemerintah Daerah Kabupaten Bengkalis.

Yoshikawa Eiji; Tinjanan Kritik Sastra Feminis (Doctoral Dissertation, Universitas Andalas).

${ }^{3}$ Rahmawati, Anita. "Harmoni dalam keluarga perempuan karir: upaya mewujudkan kesetaraan dan keadilan gender dalam keluarga." PALASTREN Jurnal Studi Gender 8.1 (2016): 1-34. 
Subjek penelitian ini PNS Di lingkungan Dinas Pemberdayaan Perempuan Dan Perlindungan Anak Pemerintah Kabupaten Bengkalis. Sedangkan populasi dari penelitian ini adalah 36 orang yang merupakan PNS yang berada dilingkungan dinas tersebut. Semua populasi ini juga dijadikan sampel dalam penelitian, sehingga data-data banyak diperoleh melalui sampel tersebut.

Data dikumpulkan dengan angket, data-data dioleh dengan menggunkana rumus.

$$
\mathrm{p}=\frac{F}{N} x 100 \%
$$

Dimana:

$$
\begin{array}{ll}
\mathrm{P} & =\text { Persentase } \\
\mathrm{F} & =\text { Frekuensi } \\
\mathrm{N} & =\text { Jumlah Data }^{4}
\end{array}
$$

Disamping itu juga dilakukan wawancara kepada informan yang sudah dipilih, terutama informan dari anggota kelompok yang mendapatkan pembinaan dan pembedayaan atau kelompok sasaran dari pada program Dinas Pemberdayaan Perempuan Dan Perlindungan Anak Pemerintah Daerah Kabupaten Bengkalis.

Kabupaten Bengkalis merupakan salah satu kabupaten dari provinsi Riau. Kabupten ini terdiri dari 11 Kecamatan, 19 Kelurahan dan 136 Desa dengan jumlah penduduk 553.938 jiwa ${ }^{5}$. Maka dengan kondisi demokrafis yang demikian, tentu pembangunan yang berlangsung di Bengkalis harus dilakukan dengan pendekatan kesetaraan dan keadilan gender itu.

\section{Hasil dan Pembahasan Pengertian Gender}

Istilah gender digunakan untuk menjelaskan perbedaan peran perempuan dan laki-laki yang

4 Anas Sudijono, Pengantar Statistik Pendidikan, Jakarta: Raja Grafindi Prasada, 2009, H. 43

${ }^{5}$ Data Pememerintah Kabuapaten Bengkalis tahun 2019. bersifat bukan bawaan sebagai ciptaan Tuhan. Gender merupakan hasil dari kontruksi sosial masyarakat, bukan yang dikontruksi oleh Tuhan ${ }^{6}$ Oleh sebab itu gender adalah pembedaan peran, kedudukan, tanggung jawab, dan pembagian kerja antara laki-laki dan perempuan yang dikonstruksi oleh masyarakat berdasarkan sifat pantas tidak pantas yang dimiliki oleh perempuan dan laki-laki menurut norma, adat istiadat, kepercayaan, dan kebiasaan masyarakat. Jika gender dikontruksi oleh sosial, maka gender adalah hal mudah dijadikan sobordinasi, diskriminasi dan seterusnya.

Gender tidak sama dengan kodrat. Kodrat adalah sesuatu yang ditetapkan oleh Tuhan TME, yang tidak dapat diubah atau ditolak oleh manusia.

Tabel 1

\section{Perbedaan Gender dan Kodrat}

\begin{tabular}{lll}
\hline \multicolumn{1}{c}{ Gender } & \multicolumn{1}{c}{ Kodrat } \\
\hline $\begin{array}{l}\text { Disiptakan } \\
\text { manusia }\end{array}$ & Tuhan Meniptakan & \\
Bisa dipertukarkan & $\begin{array}{l}\text { Tidak } \\
\text { dipertukarkan }\end{array}$ & bisa \\
Tidak universal & Universal & \\
\hline
\end{tabular}

Sehingga kodrat bersifat universal misalnya, melahirkan, menstruasi, dan menyesuai merupakat kodrat perempuan, memiliki sperma dan membuahai adalah kodrat laki-laki. Sedangkan gender adalah perbedaan peran, hak, kewajiban, kuasa, dan kesempatan antara lakilaki dan perempuan didalam kehidupan masyarakat. Gender terbentuk secara kultural, hasil konstruksi sosial dan budaya yang berbedabeda setiap letak geografis serta memilii sifat menyesuaikan dengan situasi dan kondisi.

\footnotetext{
${ }^{6}$ Esariti, L. (2016). Determinan Analisis Gender Pada Pemberdayaan Masyarakat Miskin Perkotaan. Ruang, 2(3), 189-195.
} 
Konsep gender juga termasuk karakteristik atau ciri-ciri perempuan dan laki-laki yang diciptakan oleh keluarga atau masyarakat yang dipengaruhi oleh insterpretasi budaya dan agama. Misalnya, secara umum pekerjaan memasak, menuci selalu disebut sebagai pekerjaan perempuan. Pandagan seperti ini meruapakan ciptaan masyarakat dari budaya tertentu, padahal pekerjaan tersebut bisa dipertukarkan dengan laki-laki atau dapat dikerjakan oleh laki-laki. Gender itu pandangan relative yang dibangun untuk membedakan peran laki-laki dan perempuan, kadang pandangan itu meredahkan salah satu pihak, baiak merendahkan laki-laki maupun perempuan.

Namun pandagan seperti ini bisa saja berbeda dari satu budaya dengan budaya lainya. Yang mengakibatkan perbedaan peran sosial laki-laki dan perempuan, yang disebut dengan perbedaan gender. Peran didapat beruabha dari waktu ke waktu dari suatu tempat ke tempat lainya. Peran gender yang dimiliki oleh laki-laki dan perempua akan berpengaruh pada pola relasi kuasa antara perempuan dan laki-laki ${ }^{7}$. Relasi kuasa ini, kadang-kadang yang menciptakan ketimpangan, terutama ketimpangan itu dominan berlaku untuk perempuan.

Dalam pembangunan, jika terjadi ketimpangan tersebut maka pembangunan itu tidak akan wujud sebagai peningkatan kualitas hidup manusia, aka nada pihak-pihak yang terabaikan dan termarjinalkan. Sedangkan pembangunan tujuan utamanya adalah untuk

\footnotetext{
7 Herien Puspitawati, Konsep, Teori dan Analisis Gender, Gender dan Keluarga: Konsep dan Realita di Indonesia, PT. IPB Press, Bogor:2012, h. 1
}

meningkatan kehidupan manusia dan masyarakat yang lebih sejahera. ${ }^{8}$

Oleh sebab itu pembanguan sekarang ini, diletakan dalam kerangka kesetaraan gender itu. Tidak ada kelas yang dimarjinalkan, perampuan dan laki-laki harus memiliki akses yang sama, tidak lagi perempuan berda pada kelas nomor dua atau kelas yang dipinggirkan dianggap remeh. Sering kali perempuan dianggap tidak mampu untuk menjalankan aktivitas seperti lakilaki. Seperti dibeberapa perusahan yang menolak untuk menerima karyawana perempuan karena dicap "lemah", sehingga mengharuskan perempuan untuk berada dirumah untuk mengurus rumah tangga dan perempuan menjadi terkekang. Perlakuan semacam ini menyembabkan ketimpangan gender yang didasarkan pada kodrat seorang perempuan yang berkewajiban untuk mengurus rumah.

Jadi Gender itu adalah "Gender should be conceptualized as a set of relations, existing in social institutions and reproduced in interpersonal interaction " (gender diartikan sebagai suatu set hubungan yang nyata di institusi sosial dan dihasilkan kembali dari interaksi antar personal). ${ }^{10}$ Perbedaan perempuan dan laki-laki pada hakekatnya adalah bentukan masyarakat melaluai konstruksi sosial budaya, menghasilkan peran dan tugas yang berbeda. Perbedaan peran ini menyebabkan perempuan selalu tertinggal dan terabaikan peran dan kontribusinya dalam institusi masyarakat.

Gender adalah salah satu konsep yang digunakan untuk mengidentifikasi perbedaan laki-laki dan perempuan dalam konteks sosial

8 Sulistyastuti, D. R. (2007). Pembangunan Pendidikan dan MDGs di Indonesia Sebuah Refleksi Kritis. Jurnal Kependudukan Indonesia, 2(2), 19-44.

9 Mansour Faqih, Analis Gender Dan Transformasi Sosial, Pendekatan, Pustaka Pelajar, Jogjakarta:2007, H. 7

\section{${ }^{10}$ Ibid}


budaya. Dari waktu ke waktu menempati posisi tersendiri terlepas dari penerimaan ataupun penolakan. Sehingga gender menjadi kelompok yang telah terbangun dengan sendirinya.

Pandangan gender dalam Islam, kajiankajian dari Nasaruddin Umar sangat bisa digunakan untuk menjelaskan perihal gender dalam perpsektif Islam itu ada beberapa hal yang menunjukkan bahwa prinsip-prinsip kesetaraan gender ada di dalam Al-Qur'an yakni, menurut Nazaruddin Umar ${ }^{11}$ :

a. Perempuan dan Laki-laki sama-sama sebagai Hamba Menurut Q.S al-Zariyat (51:56). Dalam kapasitas sebagai hamba tidak ada perbedaan antara laki-laki dan perempuan. Keduanya mempunyai potensi dan peluang yang sama untuk menjadi hamba yang ideal. Hamba yang ideal dalam Qur'an biasa diistilahkan sebagai orang-orang yang bertaqwa (mutaqqun), dan untuk mencapai derajat mutaqqun ini tidak dikenal adanya perbedaan jenis kelamin, suku bangsa atau kelompok etnis tertentu, sebagaimana disebutkan dalam Q.Q al-Hujurat (49:13). Semua yang diciptakna oleh Allah SWT sesuai dengan kodratnya masing-masing, karena dengan ciri khas (keistimewaan) yang dimiliki masing-masing memiliki potensi dan kekuatan yang berbeda-beda.

b. Perempuan dan Laki-laki sebagai khalifah di bumi ditegaskan dalam Q.S al-An'am (6:165), dan dalam Q.S al-Baqarah (2:30). Dalam kedua ayat tersebut, kata "khalifah" tidak menunujuk pada salah satu jenis kelamin tertentu, artinya baik perempuan maupun laki-laki mempunyai fungsi yang sama sebagai khalifah. Dalam hal ini dijelaskan bahwa manusia diciptakan untuk mengatur

11 Nasaruddin Umar, Gender Dalam Al-Qur'an, Jurnal Pemikiran Islam Tentang Pemberdayaan Perempuan, 2000, h. 27 kehidupan rakyat dan individu itulah yang bisa untuk meninggikan derajatya. Jadi baik laki-laki ataupun perempuan bisa untuk meningkatkan derajatnya sesuai dengan potensi yang dimiliki didalam dirinya.laki-laki dan perempuan mempunyai fungsi sebagai khalifah yang dapat mempertangungjawabkan tugas-tugas yang diemban, sebagaimana mereka mempertangungjawabkan sebagai hamba tuhan.

c. Perempuan dan laki-laki menerima perjanjian awal sama-sama mengemban amanah dan menerima perjanjian awal dengan Tuhan, seperti dalam Q.S al A'raf (7:172) yakni ikrar akan keberadaan Tuhan yang disaksikan oleh para malaikat. Sejak awal sejarah menusia dalam Islam tidak dikenal adanya diskriminasi jenis kelamin. Laki-laki dan perempuan samasama menyatakan ikrar ketuhanan yang sama. Qur'an juga menegaskan bahwa Allah memuliakan seluruh anak cucu adam tanpa pembedaan jenis kelamin. Q.S al-isra'(17:70).

d. Adam dan Hawa Terlibat secara Aktif dalam Drama Kosmis Semua ayat yang menceritakan tentang drama kosmis, yakni cerita tentang keadaan Adam dan Hawa di surge sampai keluar bumi, selalu menekankan keterlibatan keduanya 157 secara aktif, dengan penggunaan kata ganti untuk dua orang (huma), yakni kata ganti untuk Adam dan Hawa, yang terlihat dalam beberapa kasus sebagai berikut:

1) Kaduanya diciptakan di surga memanfaatkan fasilitas surga (Q.S alBaqarah/2:35)

2) Keduanya mendapat kualitas godaan yang sama dari setan (Q.S al-A'raf/7:20)

3) Sama-sama memohon ampun dan samasama diampuni Tuhan (Q.S al-A'raf/7:23) 
4) Setelah di bumi keduanya mengembangkan keturunan salaing melengkapi dan saling membutuhkan Q.S al-Baqarah(2:187). ${ }^{12}$

e. Perempuan dan Laki-laki Sama-sama Berpotensi Meraih Prestasi Peluang untuk meraih prestasi maksimum tidak ada pembedaan antara perempuan dan laki-laki ditegaskan secara khusus dalam 3 (tiga) ayat, yakni: Q.S Ali Imran 3:195; Q.S an-Nisa (4:124) Q.S an-Nahl (16:97). Ketiganya mengisyaratkan konsep kesetaraan gender dan ideal dan memberikan ketegasan bahwa prestasi individual, baik dalam bidang spiritual maupun karir professional, tidak mesti didominasi satu jenis kelamin saja.

\section{Penyajian dan Analisa Data}

Dinas Pemberdayaan Perempuan dan Perlindungan Anak, merupakan salah satu Dinas yang ada di pemerintah Daerah Kabupaten Bengkalis. Eksistensi daripada dinas ini sangat jelas sebagai bentuk daripada penghapusan adanya diskriminasi dan marjinalisasi, serta sekaligus untuk meningkatkan kualitas hidup manusia tanpa ada diskriminasi dan marjinalisasi itu.

Oleh sebab PNS yang ada di dinas ini harus mengetahui betul dan mempunyai program yang dapat mewujudkan keadilan gender itu, sehingga pembangun dapat menjadi agent keselamatan untuk semua pihak.

Salah satu langkah startegis yang harus diambil menandakan PNS dilingkungan suatu instansi memahamai arti penting kesetaraan gender itu adalah, ditemukannya data-data terpilah sebagai basis dalam pembuatan program. Dengan data itu melakukan perencanaan dan pematangan program, tanpa data itu maka dapat difahami program tidak

\footnotetext{
${ }^{12}$ Maslamah dan Suprapti Muzani, Konsep-Konsep Tentang Gender Perspektif Islam, SAWWA Volume 9, Nomor 2, 2014, h. 279
}

akan menemukan dampak yang signifikan sebagai pewujud kesejahteraan ${ }^{13}$.

Data terpilah itu adala indikator pertama untuk menyatakan pemahaman dari kelompok pengambil kebijakan tentang gender itu. PNS Dinas Pemberdayaan Perempuan dan Perlindungan Anak Kabupaten Bengkalis sudah membuat data terpilah tersebut, data ini selalu diperbaharu setiap tahunnya, sehingga dalam pembuatan program dilandasi oleh data-data rersebut. Data terpilah menjadi basic dasar dalam melakukan gerakan perubahan. Dari 36 PNS yang ada dilingkungan Dinas Pemberdayaan Perempuan dan Perlindungan Anak Kabupaten Bengkalis, hampir semuanya mengetahui data basis terpilah itu, dimana dari 36 orang PNS sebanyak $94 \%$ (34) orang menyatakan mengetahui, $6 \%$ (2) orang ragu-ragu dan tidak ada yang tidak mengetahuinya.

\section{Gambar 1}

\section{Pengetahuan Data Terpilah}

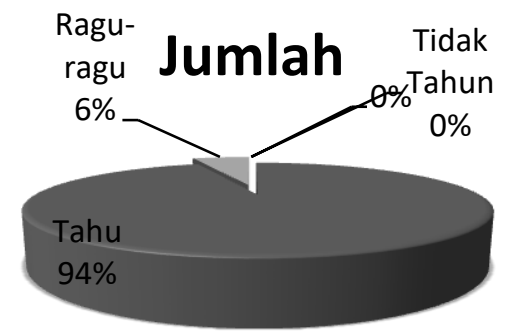

Selain itu, juga diketahui pengetahuan gender itu dalam berbagai bentuk dan indikator diantaranya seperti terlihat pada tabel 2

\section{Tabel 2}

\section{Pemahaman Gender}

\section{Pemahaman Gender \\ Indikator}

Kesetaraan dalam Akses pendidikan peningkatan kualitas diri yang setinggi-tingginya

${ }^{13}$ Darwanis, D. (2016). Analisis Anggaran Responsif Gender Sebagai Percepatan Pencapaian Target MDGs. Jurnal Akuntansi Multiparadigma, 6(3), 481-492. 


\section{Pemahaman Gender}

Indikator

Kesertaraan dalam berja

Kesempatan karir

Memperoleh peningkatan

kualitas hidup dan pola

Aktivitas dan akses

kesehatan

Mementukan dan terlibat Partisipasi dalam

dalam berbagai pembangunan

kesempatan

Berdasarkan itu, diketahui bahwa pemahaman gender PNS Dinas Pemberdayaan Perempuan dan Perlindungan Anak Pemerintah Daerah Kabupaten Bengkalis.

\section{Tabel 3}

\section{Pemahaman Gender}

\begin{tabular}{ccccc}
\hline NO & $\begin{array}{c}\text { Tingkat } \\
\text { Pemahaman }\end{array}$ & $\begin{array}{c}\text { Item } \\
\text { Pernyataan } \\
\text { Angket }\end{array}$ & $\begin{array}{c}\text { Jumlah } \\
\text { Responden }\end{array}$ & Persentasi \\
\hline 1 & $\begin{array}{c}\text { Sangat } \\
\text { Baik }\end{array}$ & 40 & 28 & $77 \%$ \\
3 & $\begin{array}{c}\text { Cukup } \\
\text { Baik }\end{array}$ & 4 & 3 & $8 \%$ \\
4 & $\begin{array}{c}\text { Kurang } \\
\text { Baik } \\
\text { Tidak } \\
\text { baik }\end{array}$ & 6 & 3 & $8 \%$ \\
& Jumlah & $\mathbf{5 4}$ & $\mathbf{3 6}$ & $\mathbf{1 0 0 \%}$ \\
\hline
\end{tabular}

Dari table 3 di atas dapat disimpulkan bahwa tingkat pemahaman gender PNS di lingkungan Dinas Pemberdayaan perempuan dan Perlindungan Anak Kabupaten Bengkalis dikategorikan mengetahui dimana sebayak $74 \%$ PNS berada dalam pemahaman gender yang sesuai dengan konsep-konsep gender itu sendiri.

Hal ini dimungkinkan, karena seringnya dilakukan workshop-workshot tentang pemahaman gender dalam berbagai aspek kehidupan di Kabupaten Bengkalis, karena saat ini pembangun harus berwawana kesetaraan gender. Oleh sebab itu PNS Dinas Pemberdayaan perempuan dan Perlindungan Anak menjadi leading sector untuk memberikan pemhaman itu. Maka secara langsung atau tidak langsi PNS di dinas ini harus manguasai dan memahami gender tersebut.

Di samping, adanya tuntutan pekerjaan di Dinas Pemberdayaan perempuan dan Perlindungan Anak untuk memahami gender itu, maka PNS harus menggali dan memahami gender baik melalui pelatihan dan jenjang pendidikan formal maupun secara otodidak.

Jika PNS dilingkungan Dinas Pemberdayaan perempuan dan Perlindungan Anak tidak memahami gender, jelas pekerjaan yang dilakukannya tidak dapat eningkatkan kualitas hidup manusia, karena kualitas itu bisa dicapai dengan meletakkan program yang sesuai dengan kebutuhan masyarakat tanpa mendiskriminasi dan memarjinalisasi. Oleh sebab itu program Pengarusutamaan Gender (PUG) menjadi hal yang mesti dikuasai oleh PNS di lingkungan ini, hal ini dimulai dari pemahaman gender itu sendiri. Jika tidak memahami gender maka tidak akan ada terwujud konsepsi program pengarusutmaan gender itu.

Pengetahuan dan pemahaman gender yang dimiliki oleh PNS di Dinas Pemberdayaan perempuan dan Perlindungan Anak ini, bisa diimplementasikan ke dalam program-program. Pada Dinas Pemberdayaan perempuan dan Perlindungan Anak Kabupaten Bengkali PNS mengimplementasikannya melalui program sebagai berikut:

a. Program kerja yang dilaksanakan dalam bentuk kegiatan maupun dalam hal kepanitiaan sudah mempertimbangkan unsur gender serta berdasarkan kemampuan dan topoksi masing-masing orang. 
b. Program kerja maupun kegiatan yang telah dilaksanakan oleh Dinas Pemberdayaan Perempuan dan Perlindungan Anak baik yang sifatnya internal maupun yang langsung bersentuhan dengan masyarakat dalam hal ini di beberapa kecamatan di Kabupaten Bengkalis sudah mempertimbangkan kebutuhan masyarakat bukan berdasarkan jenis kelamin.

c. Implementasi pemahaman gender dilingkunan Dinas Pemberdayaan Perempuan dan Perlindungan Anak Kabupaten bengkalis sudah baik hal ini dibuktikan dengan sudah terbentuknya Pokja Kelompok Kerja Pengarusutamaan Gender (PUG) di seluruh SKPD di Kabupaten Bengkalis dengan leding sektornya Bapeda sedangkan sekretaris pelaksananya adalah Dinas Pemberdayaan Perempuan dan Perlindungan Anak dengan melibatkan unsur Perguruan Tinggi.

d. Implementasi pemahaman gender dilingkunan Dinas Pemberdayaan Perempuan dan Perlindungan Anak Kabupaten bengkalis sudah baik hal ini dibuktikan dengan adanya pemberdayaan perempuan, perlingdungan perempuan, pemberdayaan anak dan perlingan anak dengan dibentuknya pusat pemberdayaan perempuan Pusat Pelayanan Terpadu Pemberdayaan Perempuan dan Anak (P2TP2A).

Respon masyarakat pada PNS Di Lingkup Dinas Pemberdayaan Perempuan Dan Perlindungan Anak Pemerintah Daerah Kabupaten Bengkalis, terlihat daripada adanya dukungan-dukungan dan realisasi daripada program yang dilakukan berkaitan dengan kesejahteraan gender, diantaranya dapat dilihat dukungan dari beberapa instansi terkait, seperti; Sebagian PNS Dinas Pemberdayaan Perempuan dan Perlindungan Anak Kabupaten Bengkais sudah terlibat secara langsung di masyarakat melalui PKK Pokja I dengan memberikan penyuluhan tentang Kekerasan Dalam Rumah Tangga (KDRT).

Beberapa kegiatan yang dilakukan oleh PNS di lingkungan Dinas Pemberdayaan Perempuan dan Perlindungan Anak Kabupaten Bengkalis yang terkait dengan pengimplementasian pemahaman gender melalui kgiatan diantaranya adalah:

a. PNS Dinas Pemberdayaan Perempuan dan Perlindungan Anak Kabupaten Bengkalis sudah terlibat langsung melalui Pokja II PKK dengan memberikan penyuluhan tentang pola asuh anak, sehingga dengan pola asuh ini masyarakat bisa memahami tentang kesejahteraan berbasis gender.

b. PNS Dinas Pemberdayaan Perempuan dan Perlindungan Anak Kabupaten Bengkalis melakukan pembinaan dan penilaian dalam Program Peningkatan Peranan Wanita Menuju Keluarga Sehat (P2WKSS), salah satu program yang merupakan untuk meningkatkan peranan wanita dalam masyarakat menuju keluarga sejahtera.

c. PNS Dinas Pemberdayaan Perempuan dan Perlindungan Anak Kabupaten Bengkalis sudah terlibat langsung dalam pendampingan dan penganan dalam permasalahan perempuan dan anak melalui melalui P2TP2A

\section{KESIMPULAN}

Berdasarkan data yang penulis dapatkan baik melalui penyebaran angket di lapangan dan wawancara secara langsundengan beberapa subjek penelitian dapat disimpulkan diantaranya PNS Dinas Pemberdayaan Perempuan dan Perlindungan Anak Kabupaten Bengkalis pada umumnya memiliki pemahaman tentang gender. Hal ini dapat dilihat dari berbagai konsepsi dan program yang disusunnya berbasis kesetaraan 
gender. PNS memiiki kesadaran, bahwa kesejahteraan tidak dapat diwujudkan jika tidak dilakukan dengan pendekatan program yang mempunyai kesetaraan gender, tidak ada yang terdiskriminasi.

Di samping itu, PNS dilingkungan Dinas Pemberdayaan Perempuan dan Perlindungan Anak Kabupaten Bengkalis, juga telah melakukan program-program untuk mewjudukan kesejahteraan berbasis kesetaraan gender itu, diantaranya melalui penyuluhan dan pembinaan kelompok-kelompok masyarakat.

Masyarakat pun memiliki respon yang positif terhadap berbagai program dan kegiatan yang terkait dengan penguatan kesetaraan gender itu, diantaranya dapat dilihat dari keikutsertaan masyarakat dalam program-program yang dilakukan oleh PNS dil ingkungan Dinas Pemberdayaan Perempuan dan Perlindungan Anak Kabupaten Bengkalis

\section{DAFTAR PUSTAKA}

Arjani NL. Ketimpangan gender di beberapa bidang pembangunan di Bali. Jurnal Studi Jender. 2003;3(2).

Darwanis, D. (2016). Analisis Anggaran Responsif Gender Sebagai Percepatan Pencapaian Target MDGs. Jurnal Akuntansi Multiparadigma, 6(3), 481-492.

Esariti, L. (2016). Determinan Analisis Gender Pada Pemberdayaan Masyarakat Miskin Perkotaan. Ruang, 2(3), 189-195.

Prosedur Penelitian. (1991). Jakarta: Renika Cipta.

Faqih, M. (2007). Analis Gender dan Transformasi Sosial, Pendekatan. Jogjakarta: Pustaka Pelajar.

Faqih, M. (2007). Analis Gender dan Transformasi Sosial, Pendekatan. . Jogjakarta: Pustaka Pelajar.

Mufaro'ah dan Titin Sumarni
Leny, O. (2016). Perlawanan Perempuan Terdadap Dominasi Laki-Laki Dalam Novel Naruto Hicho Karya Yoshikawa Eiji; Tinjanan Kritike Sastra Feminis (Doctoral Dissertation, Universitas Andalas).

Maslamah, \& Muzani, S. (2014). Konsep-konsep tentang Gender Perspektif Islam. SawwaVolume 9, Nomor 2, 276.

Maslamah, \& Muzani, S. (2014). KonsepKonsep Tentang Gender Perspektif Islam. SAWWA Volume 9, Nomor 2, 279.

Nizar, S., \& dkk. (2016). Pedoman Penulisan SKRIPSI Sekolah Tinggi Agama Islam Negeri (STAIN) Bengkalis. Bengkalis: STAIN Bengkalis.

Puspitawati, H. (2012). Teori dan Analisis Gender, Gender dan Keluarga: Konsep dan Realita di Indonesia. Bogor: PT. IPB Press.

Puspitawati, H. (2013). Teori Dan Analisis Gender, Departemen Ilmu Keluarga dan Konsumen Fakultas Ekologi Manusia. Institut Pertanian Bogor, 3-4.

Rahmawati, Anita. "Harmoni dalam keluarga perempuan karir: upaya mewujudkan kesetaraan dan keadilan gender dalam keluarga." PALASTREN Jurnal Studi Gender 8.1 (2016): 1-34.

Rusli, M. (2011). Konsep Gender Dalam Islam. Jurnal Ilmiah Kajian Gender, Kafa'ah Volume 1 No. 2, 152.

Sudijono, A. (2007). Pengantar Statistik Pendidikan. Jakarta: PT. Raja Gravindo Persada.

Sudijono, A. (2009). Pengantar Statistik Pendidikan. Jakarta: Raja Grafindi Prasada.

Suharsimi. ( 2014). Prosedur Penelitian: Suatu Pendekatan Praktik. Jakarta: Renika Cipta.

Sujarweni, V. (2014). Metodelogi Penelitian. Jogjakarta: PustakaBaruPres.

Sulistyastuti, D. R. (2007). Pembangunan Pendidikan dan MDGs di Indonesia Sebuah Refleksi Kritis. Jurnal Kependudukan Indonesia, 2(2), 19-44. 
Umar, N. (2000). Gender Dalam Al-Qur'an. Jurnal Pemikiran Islam Tentang Pemberdayaan Perempuan, 27.

Umar, N. (2002). Qur'an untuk Perempuan . Jakarta: Jaringan Islam Liberal (JIL) dan Teater Utan Kayu. 